EPiC Series in Biological Sciences
Volume 1, 2021, Pages 79-85
$\begin{gathered}\text { Proceedings of KOBI 2nd International Confer- } \\ \text { ence on Management of Tropical Biodiversity for } \\ \text { Human Welfare: From Ecosystem to Molecular }\end{gathered}$

\title{
The Impact of PjBL to Students' HOTS in Human Excretion System Material
}

\author{
Ilham Mubassyr $^{1 *}$, Hanum Mukti Rahayu ${ }^{1}$, and Nuri Dewi Muldayanti ${ }^{1}$ \\ ${ }^{1}$ Universitas Muhammadiyah Pontianak, Indonesia \\ ilham. mubassyreunmuhpnk.ac.id
}

\begin{abstract}
This research is an experimental study of an Impact of PjBL on Students' HOTS in Human Excretion System Material. This research was conducted at SMP Muhammadiyah 1 Pontianak in the odd semester of the 2018/2019 academic year. Before conducted this research, the researcher first observed two months of advanced internship activities from October until November 2018. The study used class VIII D with 25 people for the experimental class and class VIII C with 27 people for the control class. Projects that students will make include the excretory system organ and its functions. The purpose of this study was to: (1) determine the effect of PjBL on students' HOTS in the human excretion system material. (2) To find out the difference between PjBL and learning using cooperative learning type make a match to students' HOTS in the Human Excretion System material. Independent sample t-test results obtained a significance value of 2tailed at 0,000 . Because of the significance value $<0.05$, it can be concluded that $\mathrm{PjBL}$ is very influential in students' HOTS. Project-based learning has a very high influence on students' HOTS with an effect size of 1.29 and is included in the very high category.
\end{abstract}

\section{Introduction}

The problems of education in Indonesia is still the low quality of education and the uneven implementation of education. It is aware that Indonesia is an archipelagic country so that the quality of human resources that are considered qualified only focused on certain areas in Indonesia. To minimize a gap, the government, and education specialists strive to improve the quality of education and equity. Facing the problems above, the role of local government is crucial in improving the human resource base begins secondary education and one of the subjects at junior high schools, namely the Natural Sciences (Kawawung, 2011).

Hanoum (2014) says that learning is an activity that is individualized each learner has learning styles and motivation is different from one another. It affects how far learners can succeed in learning. However, the teacher's role is also very important, especially related to the learning atmosphere that is created and used learning strategies. Learning strategy which is ideal to develop higher-level thinking 
skills is a strategy that starts with students (student-centered). Learning centered on learners enable learners to express their ideas openly and develop higher-level thinking skills.

The ability to think critically or often called HOTS (Higher Order Thinking Skills), can make an individual interpret, analyze, or manipulate information that can be seen from the students at the level of analysis, synthesis, and evaluation (Kawawung, 2015). The ability to think critically not only requires the ability to remember but also requires the ability to think critically and creatively (Rosnawati, 2009).

There are several indicators of when a person is said to have a HOTS. Indicators to measure HOTS include (Saregar, Latifah, \& Sari, 2016): (1) analyzing, separating the material into parts preparation and detect how one part relates to the other part; (2) Distinguishing, learners can distinguish between the irrelevant and relevant or essential part to part is not important from a materials provided; (3) Organizing, learners can determine how the elements fit and able to work together within a structure; (4) Linking, learners can define the core concept of the material being studied; (5) Evaluate, able to make decisions based on standard criteria, such as checking and criticize.

To develop this HOTS, educators are required to create a learning atmosphere that supports and uses learning strategies that can facilitate the learners in the process of HOTS. One way to do is to use appropriate learning media, which not only can help learners to understand the learning materials but also make learners active in processing messages or material that must be mastered. Along with the development of technology, based learning technology media is also growing and increasingly easy to be adapted and used for learning purposes (Hanoum, 2014).

Learning strategies that facilitate students and make learners will be more active in the learning activities such as discussions, questions and answers, and group work that requires interaction and cooperation PjBL (Project Based Learning). Project-based learning is an instructional model that involves a project in the learning process. Project in which students can be individual or group project and implemented within a certain period of collaborative, resulting in a product, the results of which will then be displayed and presented. Implementation of the project is done in collaboration and innovative, unique, which focuses on solving problems related to student life (Jagantara, Adnyana, \& Widiyanti, 2014).

Based on an activity-based learning project, carried out in three phases namely preparation, learning, and evaluation, but three of these stages can be described into six stages as follows (Hutasuhut, 2010): (1) Preparations, teacher visually design or create a template project helpful in providing the information needed by students in developing the idea for the project following the existing framework, and provide resources to assist the process; (2) Assignment / determine the topic, according to project tasks assigned by the teacher as well as his own choice, students will obtain and read the framework of the project, and then trying to find resources that can help; (3) Plan activities, students work on individual projects, group in one class or between classes. students determine the activities and measures to be taken per sub-topic, plan the time of execution of all sub-topic; (4) Investigation and presentation, investigation here, including activity asking the experts and exchange of experiences and knowledge between groups. In the process, sometimes with observation and experiment; (5) Finishing, students make a report, presented in class. As a result of its activities. Then the teacher and student make a note on the project for further development. Learners receive feedback on what they make of the group, friends, and teachers; (6) Monitoring / Evaluation, teachers assess all project processes performed by each group based on participation and productivity in the project.

In addition to the use of strategies and methods of student-centered learning, the use of evaluation questions also plays a role in the increase in HOTS. During this time the teacher uses only a matter of evaluation in the form of multiple-choice questions. The use of multiple-choice instruments can only assess content knowledge without considering the reasons behind the choice (Shidiq, 2014). One instrument that can be used is the Two-tier Multiple Choice (TTMC), which forms more sophisticated questions of multiple-choice questions. The first level resembles a traditional multiple-choice, which is usually associated with that knowledge. The second level resembles the format of traditional multiplechoice questions but aims to encourage thinking and reasoning skills that higher (Higher Order Thinking 
Skills) (Shidiq, Masykuri, \& Susanti, 2014). The form about a two-tier test developed by David Treagust of Curtin University in Australia. The shape of this matter is that each item contains two parts.

Based on the results of direct observation and interviews with science teachers in SMP Muhammadiyah 1 Pontianak, in the learning process of teachers not using the learning model that dotted on students, teachers still use the lecture method of teaching time and failed to give the freedom for students to explore their information. Meanwhile, according to Hanoum (2014), Learning centered allows learners to express their ideas openly, and develop thinking skills. Based on the learning process of high-level thinking skills students have not been trained also based on learning factors that are not yet using models or methods that may make the students express their ideas openly.

Based on these problems it is necessary to research the improvement of HOTS of students by using models or methods that start on students (student-centered), which enables students to express their ideas openly. The method can be used that PjBL (Project-Based Learning). HOTS measured by multiple-choice questions story (Two Tier Multiple Choice).

\section{Materials and Methods}

The research was conducted in SMP Muhammadiyah 1 Pontianak. This experimental study carried out in the second semester of the academic year 2018/2019. Previous researchers have made observations through an apprenticeship that began in October 2018. The method used is the experimental method. The experimental method can be interpreted as the methods used to find a specific treatment effect against the other under controlled conditions. This experimental method of dividing the object to be studied into two groups: the experimental group learning using PjBL (Project Based Learning) and the control group using cooperative learning Make A Match.

The shape of the study is a quasi-experimental (Quasi-Experimental Design) because researchers can't control all the variable's external variables that affect the implementation of the study. Based on this experimental form design that used is Nonequivalent Control Group Design. Nonequivalent control group design can see the difference in achievement between control class and experimental class achievement.

The instrument in this research using a Two-tier Multiple-Choice question as many 15 questions to measure the ability to think critically. Before the instrument used in the study first tested the validity, reliability, power difference, and level of difficulty. Data analysis using IBM's SPSS 20.0 for normality test, homogeneity, and hypotheses.

A normality test is performed to determine whether the sample data were normally distributed or not. To test for normality in this study used the Shapiro-Wilk test on the IBM program SPSS 22.0 statistical significance level of 5\%. The test conditions are normal if Sig. $>0.05$ and test conditions are Abnormal if Sig. $<0.05$.

After being tested for normality and normal distribution of data, then performed a test of homogeneity of variance. The homogeneity test aims to determine whether the data from the experimental class and control class have the same variance or not. To test the homogeneity in this study using the test of homogeneity of variances on program IBM SPSS 22.0 statistical significance level of 5\%. The test criteria are homogenous if Sig. $>0.05$ and test criteria are not homogenous if the Sig. $<0.05$. If the data is said to be normally distributed and homogeneous, then followed by a test of independent sample t-test to test the hypothesis in the program SPSS 22.0. The statistical significance level of $5 \%$ of the test conditions is shown in Table 1. 


\begin{tabular}{cll}
\hline Sig. & \multicolumn{1}{c}{ Information } & \multicolumn{1}{c}{ that is to say } \\
\hline Sig. $>$ & Ho is accepted, & No difference between the HOTS experimental class and control \\
0.05 & Ha rejected & class \\
Sig. & Ho is accepted, & There are differences in the HOTS between the experimental class \\
$<0.05$ & Ha rejected & and control class \\
\hline
\end{tabular}

Table 1: Terms of Hypothesis Testing

A score of the pretest and posttest grade the students in experiment and control class with a score as followed:

\begin{tabular}{llc}
\hline \multicolumn{1}{c}{ Student's Answer } & \multirow{2}{*}{ Score } \\
\hline First Tier & Second Tier & 3 \\
Right & Right & 2 \\
Right & False & 1 \\
False & Right & 0 \\
False / No answer & False / No answer & 0
\end{tabular}

Table 2: Two-Tier Test Scoring Models according to Wulandari, Yamtinah, \& Saputro (2015)

Measurement results are analyzed using the gain value.

Gain Value $=$ Sposttest - Spretest

Impact of PjBL to the HOTS effect size was calculated using the following formula by Sutrisno (2008):

$$
\mathrm{ES}=\frac{\bar{X}_{\mathrm{e}}-\bar{X}_{\mathrm{c}}}{\mathrm{S}_{\mathrm{c}}}
$$

in which ES: effect size, $\bar{X}_{e}$ : average value of the experimental class, $\bar{X}_{c}$ : average value of the control class, and Sc: Standard deviation control class. The effect size is small if $\mathrm{d}<0.2$, moderate if $0.2<\mathrm{d}$ $<0.8$, and high if $\mathrm{d}>0.8$.

\section{Results and Discussion}

\subsection{Recapitulation of the pretest and posttest students HOTS experimental class and control class}

Following the data acquisition value of students HOTS experimental class and control, the class can be seen in Table 3 .

\begin{tabular}{lllc}
\hline \multirow{2}{*}{ Class } & \multicolumn{2}{c}{ Result } & \multirow{2}{*}{ Gain Value } \\
\cline { 2 - 3 } & Pretest & Posttest & \\
\hline Experiment & 28.62 & 80.09 & 51.47 \\
Control & 30.96 & 72.34 & 41.37 \\
\hline
\end{tabular}

Table 3: Average Value of Students' HOTS

Table 3 shows the results of the average value of high order thinking skills of students before (pretest) and after (posttest) given the learning that is using $\mathrm{PjBL}$ in the classroom cooperative learning experiment and makes a match the control class. The initial value (pretest) in the second class have relatively the same value, although there are significant differences, but not by a margin of 2.34 higher in class control. While the final scores (posttest) in both classes have significant differences with a 7.75 
higher margin in the experimental class. Such differences need to do further testing of them is normality test, homogeneity, and hypothesis testing.

Based on the research that has been done students HOTS before being given treatment can be said low, it is seen from the results of the pretest is given. The results obtained in the experimental class and control class no one has reached the minimum completeness criteria with an average value of 28.62 at the experimental class and 30.96 in the control class. These results show students haven't been able to work on the problems with the type of problem-oriented HOTS. Problem two-tier multiple-choice type can measure the level of students HOTS (analysis, evaluation, creation) (Nofiana, Sajidan, \& Puguh, 2014, p. 72) so that the student's HOTS need to be improved with treatment.

After being given a treatment using the PjBL model the experimental class and cooperative learning model make a match in control class, the result of students HOTS experienced a high increase by an average of 80.09 in experimental class and 72.34 in the control class. The increase in HOTS is affected by the treatment of learning with the PjBL model. Based on these results it appears that the PjBL(Project-Based Learning) has a positive impact on students' HOTS.

\subsection{Differences in Learning Results of Higher Order Thinking Skills between Students with Project-Based Learning and Make-A-Match Type of Cooperative Learning}

Differences result in high order thinking skills of students that could be identified after the learning process and have been carried out. The data of high order thinking skills of students in both experimental class and control classes were normally distributed with a significance of $>0.05$. Homogeneity data of students' high order thinking skills have a significance of 0.874 or $>0.05$. Based on these data we can conclude that the variance between the same groups or homogeneous. After the data were normally distributed and homogeneous then followed by a hypothesis test to determine differences in the results of the t-test. T-test result data can be seen in Table 4 below.

\begin{tabular}{lcl}
\hline \multicolumn{1}{c}{ Data } & Sig. (2-tailed) & \multicolumn{1}{c}{ Conclusion } \\
\hline $\begin{array}{l}\text { High order } \\
\text { thinking skills }\end{array}$ & 0,000 & $\begin{array}{l}\text { There are differences in the ability to think critically } \\
\text { between the experimental class and control class }\end{array}$ \\
\hline
\end{tabular}

Table 4: Hypothesis test results of high-level thinking skills

As seen in Table 4, the test resulted in an independent sample t-test obtained a 2-tailed significance value of 0.000 . Hence the significance value is $<0.05$ then Ho is rejected meanwhile Ha accepted and concluded that there are differences in the ability to think critically between students in experimental class using $\mathrm{PjBL}$ with control class using cooperative learning with making a match. The average score of students' HOTS in the experimental class is higher than the average score of the control class. Therefore, it can be concluded that the student's HOTS class experiment using PjBL is different from the student's HOTS control class using cooperative learning to make a match.

The high results of students' HOTS of human excretion system materials in class because the experiment can be explained as follows. According to Daryanto (2014), the benefit of PjBL as learning models among which are that the learning process was fun, more students were actively involved in the learning process, and students were more motivated. A fun learning environment makes students enjoy learning so that students understand the concept of the material easily. Students in groups design and plan how to accomplish the task given project teacher. The learning process is mostly done with the discussion, not only to listen to the explanation of the teacher course material so that the learning in class can be more interesting and not boring. 


\subsection{The Impact of PjBL to the Student's HOTS}

The effect of project-based learning in this study were calculated using effect size. The effect size used as a measure of the degree of success in research (Huck, 2012). PjBL differences in the ability to think critically using the formula effect size. The results of the analysis of the effect size can be seen in Table 5 below.

\begin{tabular}{lcccc}
\hline \multicolumn{1}{c}{ Class } & Gain Values & Std. Deviation & Effect Size & Criteria \\
\hline Experiment & 51.47 & 7.79 & \multirow{2}{*}{1.29} & Very high \\
Control & 41.37 & 7.78 & & \\
\hline
\end{tabular}

Table 5: The Effect Size of Students' HOTS

As seen in Table 5, the acquisition effect size is 1.29 or included in the category of very high. It indicates that the PjBL provides a very high effect on students' HOTS in science, especially in the material of the excretory system. This result also indicates that the implementation of PjBL (Project Based Learning) leads to better HOTS among students compared to the control class. In this case, the teacher may implement PjBL to increase the students' HOTS, especially in SMP Muhammadiyah 1 Pontianak.

\section{Acknowledgment}

The first author thanks Mrs. Hanum Mukti Rahayu, M.Sc., and Mrs. Nuri Dewi Muldayanti, M.Pd. as supervisors who have helped and were directly involved in the preparation of this article.

\section{References}

Daryanto. 2014. Pendekatan Pembelajaran Saintifik Kurikulum 2013. In Bahasa. Yogyakarta: Gava Media.

Hanoum RN. 2014. Mengembangkan Keterampilan Berpikir Tingkat Tinggi Mahasiswa Melalui Media Sosial. In Bahasa. Edutech. 13(3): 400-408.

Huck S. 2012. Reading Statistics and Research. Knoxville: University of Tennessee.

Hutasuhut S. 2010. Implementasi Pembelajaran Berbasis Proyek (Project-Based Learning) untuk Meningkatkan Motivasi dan Hasil Belajar Mata Kuliah Pengantar Ekonomi Pembangunan pada Jurusan Manajemen FE Unimed. In Bahasa. Pekbis Jurnal. 2(1): 196-207.

Jagantara IM, Adnyana P, and Widiyanti NL. 2014. Pengaruh Model Pembelajaran Berbasis Proyek (Project Based Learning) terhadap Hasil Belajar Biologi ditinjau dari Gaya Belajar Siswa SMA. In Bahasa. E-Journal Program Pascasarjana Universitas Pendidikan Ganesha.

Kawawung F. 2011. Profil Guru, Pemahaman Kooperatif NHT, dan Kemampuan Berpikir Tingkat Tinggi di SMP Kabupaten Minahasa Utara. In Bahasa. El-Hayati. 1(4): 157-166.

Nofiana M, Sajidan, and Puguh. 2014. Pengembangan Instrumen Evaluasi Two-Tier Multiple Choice Question untuk Mengukur Keterampilan Berpikir Tingkat Tinggi pada Materi Kingdom Plantae. In Bahasa. Jurnal Inkuiri. 3(2): 60-74.

Rosnawati R. 2009. Enam Tahapan Aktivitas dalam Pembelajaran Matematika untuk Mendayagunakan Berpikir Tingkat Tinggi Siswa. In Bahasa. Prosiding Seminar Nasional Penelitian, Pendidikan dan Penerapan MIPA Fakultas MIPA (pp. 507-512). Yogyakarta: Universitas Negeri Yogyakarta. 
Saregar A, Latifah, S, and Sari M. 2016. Efektivitas Model Pembelajaran Cups: Dampak Terhadap Kemampuan Berpikir Tingkat Tinggi Peserta Didik Madrasah Aliyah Mathla'ul Anwar Gisting Lampung. In Bahasa. Jurnal Ilmiah Pendidikan Fisika Al-Biruni. 05(2), 233-243.

Shidiq A, Masykuri M, and Susanti EV. 2014. Pengembangan Instrumen Penilaian Two-tier Multiple Choice untuk Mengukur Keterampilan Berpikir Tingkat Tinggi (Higher Order Thinking Skills) pada Materi Kelarutan dan Hasil Kali Kelarutan untuk Siswa SMA/MA kelas XI. In Bahasa. Jurnal Pendidikan Kimia. 3(4): 83-92.

Sugiyono. 2011. Metode Penelitian Kualitatif, Kuantitatif, dan $R \&$ D. In Bahasa. Bandung: Alfabeta.

Sutrisno L. 2008. Review Literatur Pendidikan IPA SD. In Bahasa. Pontianak: FKIP Untan.

Wulandari R, Yamtinah S, and Saputro S. 2015. Instrumen Two Tier Test Aspek Pengetahuan untuk Mengukur Ketrampilan Proses Sains (KPS) pada Pembelajaran Kimia untuk Siswa SMA/MA Kelas XI. In Bahasa. Jurnal Pendidikan Kimia. 4(4): 147-155. 